\title{
A STUDY OF \\ METHOXYFLURANE ANAESTHESIA
}

\author{
R. A. MiLlaR, M.D. (EDIN.), M.SC., F.F.A.R.C.S., * AND \\ M. E. MORRIS, M.D., C.M.*†
}

DURING ANAESTHESIA with methoxyflurane (1,1-difluoro 2,2-dichloro ethyl methyl ether: $\mathrm{CH}_{3}-\mathrm{O}-\mathrm{CF}_{2} \mathrm{CHCl}_{2}$ ), hypotension occurs as depth increases, ${ }^{1}$ while arfonad infusion is said to have a greater effect than with other anaesthetic agents. ${ }^{2}$ These and other clinical observations have stimulated this brief report, which concerns an assessment of sympatho-adrenal and other responses during a steady state of methoxyflurane anaesthesia in dogs, and during subsequent periods of hypercarbia and haemorrhagic hypotension.

\section{METHOD}

Eight dogs (average weight about $10 \mathrm{~kg}$.) were anaesthetized with 2.5 per cent thiopental and the trachea was intubated with a no. 10 cuffed Magill tube, which was connected via a Ruben non-rebreathing valve to a $10-\mathrm{L}$. flow of 100 per cent oxygen. Two animals were allowed to breathe spontaneously throughout the entire study; the remaining six were ventilated with a Bird respirator (Marks 4 and 8). A temoral artery was cannulated for collection of blood samples, and recording of blood pressure (Statham transducer and Sanborn recorder). Heparin (Connaught Labs. 1,000 units/ml.) was given to all dogs in an initial dose of $2 \mathrm{mg} . / \mathrm{kg}$., supplemented by $1 \mathrm{mg} . / \mathrm{kg}$. in three studies.

After the initial period of breathing 100 per cent oxygen (the average total thiopentâl dosage being $23 \mathrm{mg}$. $/ \mathrm{kg}$.) control blood samples were taken and the oxygen flow was directed through methoxyflurane in a Boyle's ether bottle, adjusted to give average concentrations of approximately 0.6 per cent (range 0.55 to 0.78 per cent). Blood samples were withdrawn 30,60 , and 120 minutes after starting methoxyflurane administration. Thereafter, in five experiments (two with spontaneous respiration and three with controlled ventilation), 20 per cent carbon dioxide in oxygen was used as the vehicle for vaporizing methoxyflurane, and further blood samples were collected after 30 and 60 minutes. In the remaining three studies, the dogs were subjected to a haemorrhage of approximately $20 \mathrm{ml} . / \mathrm{kg}$., and a second haemorrhage of $10-14 \mathrm{ml} . / \mathrm{kg}$., blood samples for assay being taken approximately 15 minutes after each haemorrhage.

Each blood sample included $35 \mathrm{ml}$. for plasma adrenaline and noradrenaline assay, ${ }^{3} 2 \mathrm{ml}$. for blood glucose estimation, ${ }^{4,5}$ and $8 \mathrm{ml}$. collected anaerobically for determination of $\mathrm{pH}$ and $\mathrm{pCO}_{2}$ of whole blood and bicarbonate of separated

*Department of Anaesthesia, Montreal Neurological Institute \& McGill University, Montreal, Quebec.

fIn receipt of a Sir Edward W. Beatty Memorial Scholarship.

Can. Anaes. Soc. J., vol. 8, no. 3, May, 1961. 

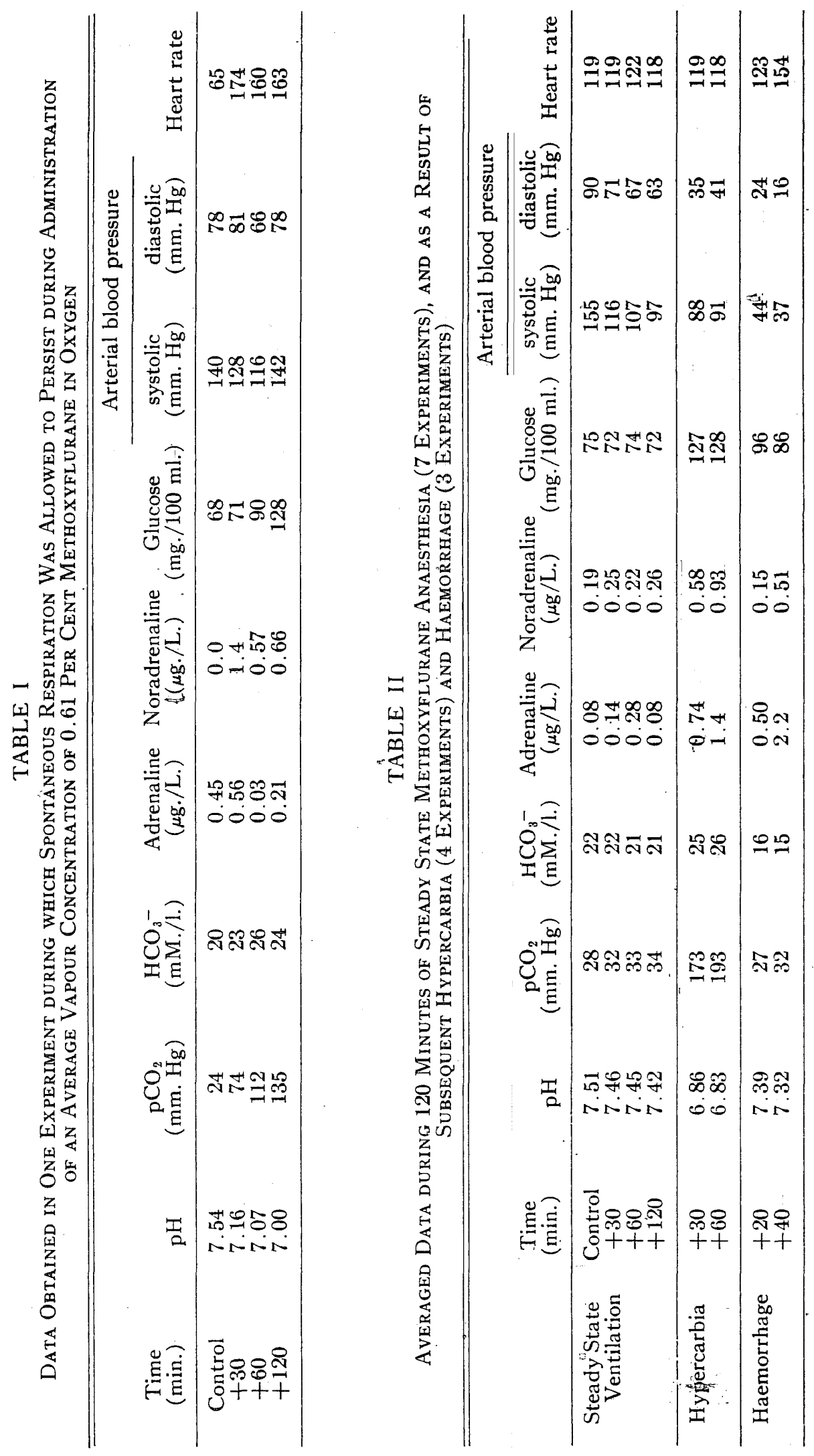
plasma at a $\mathrm{pCO}_{2}$ of $40 \mathrm{~mm}$. $\mathrm{Hg}^{6}{ }^{6}$ After each sample an equal volume of normal saline was injected intravascularly.

Student's t-test was employed for statistical analysis of the data.

\section{RESULTS}

When these studies were begun, the intention was to assess some effects of methoxyflurane during both spontaneous and controlled respiration, but in one early experiment respiratory depression was so pronounced that progressive severe carbon dioxide accumulation occurred as anaesthesia continued (Table I). In the dog, methoxyflurane is clearly a potent respiratory depressant in concentrations below 1 per cent. Subsequent experiments were therefore conducted with controlled respiration. Muscle relaxants were not required to prevent spontaneous respiratory movements during ventillation with methoxyflurane.

Table II presents the average data obtained from seven experiments, and shows that during a steady state of methoxyflurane anaesthesia lasting for two hours, within an average arterial $\mathrm{pCO}_{2}$ range of $25-35 \mathrm{~mm}$. $\mathrm{Hg}$, no consistent or statistically significant changes in plaşma adrenaline or noradrenaline could be detected. The acute respiratory acidosis induced by ventilation with 20 per cent carbon dioxide in oxygen during methoxyflurane anaesthesia, evidenced by the lowered $\mathrm{pH}$ and increased $\mathrm{pCO}_{2}$, caused consistent increases in plasma catecholamine concentrations. The rise in plasma adrenaline, from $0.15 \mu \mathrm{g} . / \mathrm{L}$. at a $\mathrm{pCO}_{2}$ of $32 \mathrm{~mm}$. $\mathrm{Hg}$ to 0.74 at a $\mathrm{pCO}_{2}$ of $173 \mathrm{~mm}$. $\mathrm{Hg}(30 \mathrm{~min}$.), and to $1.4 \mu \mathrm{g} . / \mathrm{L}$. at a $\mathrm{pCO}_{2}$ of $193 \mathrm{~mm}$. Hg (60 min.), was highly significant $(\mathrm{p}<0.01)$. Plasma noradranline increased significantly $(\mathrm{p}<0.05)$ from $0.23 \mu \mathrm{g}$. $/ \mathrm{L}$. to $0.58 \mu \mathrm{g}$. $/ \mathrm{L}$. after 30 min., and increased further to $0.93 \mu \mathrm{g} . / \mathrm{L}$. after $60 \mathrm{~min}$. (not significant statistically because of the wider range of values measured).

As a result of haemorrhage (three experiments), highly significant increases in plasma adrenaline occurred $(\mathrm{p}<0.01$ ), from $0.15 \mu \mathrm{g} . / \mathrm{L}$. to 0.50 and $2.2 \mu \mathrm{g} . / \mathrm{L}$. after the first and second haemorrhages respectively. The smaller increase in plasma noradrenaline evident after the second bleeding was not significant. Haemorrhage induced hypotension, tachycardia, and a metabolic acidosis.

Little change in blood glucose occurred during the 120 minutes of uncomplicated methoxyflurane anaesthesia, but hypercarbia was accompanied by highly significant rises $(p<0.01)$. Blood glucose also increased as a result of haemorrhage, but not significantly.

Mean arterial pressure decreased gradually during methoxyflurane anaesthesia, from an average control level of $110 \mathrm{~mm}$. $\mathrm{Hg}$ to $74 \mathrm{~mm}$. $\mathrm{Hg}$ after two hours, the greater change being in systolic pressure. Heart rate increased in five experiments and decreased in three. The early response to carbon dioxide was a consistent fall in diastolic pressure, with more variable changes in systolic pressure. After one hour of hypercarbia, mean arterial pressure was decreased to $57 \mathrm{~mm}$. $\mathrm{Hg}$, largely accounted for by the reduced diastolic pressure.

In two initial studies, spontaneous respiration was allowed to continue during methoxyflurane administration. In one of these, arterial $\mathrm{pCO}_{2}$ increased only moderately, to a maximum of $55 \mathrm{~mm}$. $\mathrm{Hg}$, and the findings are included in the 
average data shown in Table II. In the other experiment, which is excluded from the averaged results, the respiratory rate after two hours of 0.61 per cent methoxyflurane was only 2 per min. at an arterial $\mathrm{pCO}_{2}$ of $135 \mathrm{~mm}$. $\mathrm{Hg}$ (Table I). In this study plasma noradrenaline concentrations were consistently higher than in any of the other seven experiments, although the early rise from a zero level at a $\mathrm{pCO}_{2}$ of $24 \mathrm{~mm}$. $\mathrm{Hg}$ to $1.4 \mu \mathrm{g} / \mathrm{L}$. at a $\mathrm{pCO}_{2}$ of $74 \mathrm{~mm}$. $\mathrm{Hg}$ was not fully maintained thereafter.

No cardiac arrhythmias were noted on the blood pressure record during methoxyflurane administration. In one study an arrhythmia which was present after intubation was briefly accentuated when an abrupt increase in heart rate occurred as methoxyflurane was started, but a normal rhythm quickly followed. In no study were cardiac arrhythmias observed during the period of hypercarbia.

\section{Discussion}

These studies show that in the dog plasma adrenaline and noradrenaline levels are not significantly increased during anaesthesia with methoxyflurane (average concentrations $0.55-0.78$ per cent in oxygen). In this respect, therefore, methoxyflurane resembles halothane, ${ }^{7}$ but differs from diethyl ether, which in this laboratory has been found to induce consistent rises in plasma adrenaline and noradrenaline in dogs. ${ }^{8}$

The increased plasma catecholamine levels measured as a result of hypercarbia and haemorrhage during methoxyflurane anaesthesia show that sympathoadrenal responses are not completely-blocked by this agent when given in the concentrations employed for this study, these concentrations produced marked respiratory depression if spontaneous respiration was permitted. In this regard, methoxyflurane is similar to other anaesthetic agents, none of which appears to prevent catecholamine liberation from adrenal medulla and sympathetic nerves in response to the stresses of hypercarbia and haemorrhage. ${ }^{8}$ It should be noted, however, that the increases in total plasma catecholamine level resulting from haemorrhage or hypercarbia during methoxyflurane anaesthesia were less than those previously measured during anaesthesia with halothane. ${ }^{7}$ This could be interpreted as an indication of greater suppression of central or peripheral reflex sympatho-adrenal responses with methoxyflurane than with halothane, although for an accurate comparison of the two agents further studies would be required. It can only be stated that if some degree of sympatho-adrenal inhibition does occur during methoxyflurane anaesthesia, then the effect is incomplete.

Average mean arterial blood pressure levels before and after 120 minutes of methoxyflurane anaesthesia were almost identical to those measured in the similar study on dogs anaesthetized with 2 per cent halothane. ${ }^{7}$ The consistent fall in diastolic pressure in response to hypercarbia was also common to both studies. During "steady state" ventilation, consistent bradycardia occurred with halothane but not with methoxyflurane. During halothane anaesthesia the heart rate increased as a result of hypercarbia to levels similar to those which were maintained before and during the hypercarbic state in methoxyflurane anaesthesia. 
The stable blood glucose levels during 120 minutes of methoxyflurane anaesthesia and the increases with hypercarbia and haemorrhage correlate well with the plasma catecholamine concentrations. Wasmuth et al. ${ }^{9}$ found an increase in blood glucose during clinical anaesthesia with methoxyflurane. Studies are obviously required in man, but it seems clear that the increased plasma catecholamine and blood glucose levels induced by diethyl ether in the dog are not seen with methoxyflurane. The severe respiratory depression produced by methoxyflurane in dogs apparently does not occur to the same degree in man. This interesting species difference merits further investigation.

\section{SUMMARY}

Methoxyflurane anaesthesia in dogs produced respiratory depression, a gradual moderate decline in blood pressure with minimal changes in heart rate, and no significant effect on blood glucose or plasma adrenaline and noradrenaline levels. Hypercarbia induced an immediate hypotensive response and caused significant increases in both catecholamines; haemorrhage was followed by significant increases in plasma adrenaline. Blood glucose increased as a result of hypercarbia and haemorrhage during methoxyflurăne anaesthesia.

\section{ACKNOWLEDGMENTS}

These studies were supported partly by a grant-in-aid from the Cooper Fund of McGill University. The technical assistance of Mrs. J. C. Joba is acknowledged. Methoxyflurane (Penthrane) was supplied by Abbott Laboratories, Montreal.

\section{RÉSUMÉ}

L'anesthésie au méthoxyflurane, che $\iota$ les chiens, s'accompagne d'une dépression respiratoire, d'une chute modérée graduelle de la tension artérielle avec des changements minimes du rythme cardiaque mais elle demeure sans effet important sur le taux de glucose sanguin, pas plus que sur le taux d'adrénaline et de noradrénaline plasmatiques. L'hypercarbie a entraîné une hypotension immédiate et a produit une augmentation importante des catecholamines; l'hémorragie a entraîné une augmentation importante du taux d'adrénaline plasmatique. Au cours de l'anesthésie au méthoxyflurane, à cause de l'hypercarbie et de l'hémorragie, le taux deglucose sanguin a augmenté.

\section{REFERENCES}

1. Artusio, J. F, Jr.; van Poznak, A.; Hunt, R. E.; Tiers, F. M.; \& Alexander, M. Methoxyflurane in Man. Anesthesiology 21:512 (1960).

2. van Poznak, A, Ray, B. S., \& Artusio, J. F., JR. Methoxyflurane as an Anesthetic for Neurological Surgery. J. Neurosurg. 17: 477 (1960).

3. Millar, R A., Keener, E B, \& Bevfey, B. G. Plasma| Adrenaline and Noradrenaline After Phenoxybenzamine, and during Haemorrhagic Hypotension in Normal and Adrenalectomized Dogs. Brit. J. Pharmacol 14: 9 (1959). 
4. Somogyi, M. Determination of Blood Sugar. J. Biol. Chem. 160:69 (1945).

5. Somogyi, M. Notes on Sugar Determination. J./Biol. Chem. 195: 19 (1952).

6. Astrup, P. A Simple Electrometric Technique for the Determination of Carbon Dioxide Tension in Blood and Plasma, Total Content of Carbon Dioxide in Plasma, and Bicarbonate Content in "Separated" Plasma at a Fixed Carbon Dioside Tension (40 mm. Hg). Scand. J. Clin. Lab. Invest. 8: 33 (1956).

7. Millar, R. A., \& Morris, M. E. Induced Sympathetic Stimulation during Halothane Anaesthesia. Canad. Anaesth. Soc. J. 7: 423 (1960).

8. Millar, R. A., \& Morris, M. E. To be published.

9. Wasmuth, C. E.; Grieg, J. H.; Homi, J.; Moraca, P.; Niyazi, H.; Bitte, E. M.; \& Hale, D. Methoxyflurane-A New Anesthetic Agent: A Clinical Evaluation Based on 206 Cases. Cleveland Clinic Quarterly 27: 174 (1960). 